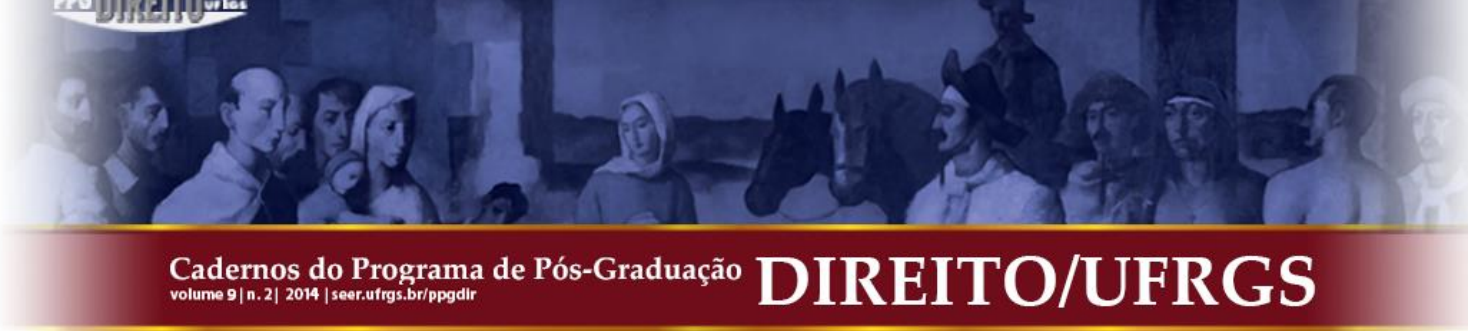

\title{
PROPAGANDA ELEITORAL NEGATIVA NAS ELEIÇÕES: LIMITAÇÕES À LIBERDADE DE EXPRESSÃO DOS CANDIDATOS E DOS ELEITORES
}

\author{
NEGATIVE ELECTORAL PROPAGANDA: LIMITATIONS TO THE CANDIDATES'AND \\ THE VOTERS' FREEDOM OF SPEECH
}

\author{
Aline Boschi Moreira* \\ Joana de Souza Sierra*
}

\begin{abstract}
RESUMO: Este artigo visa destacar os limites impostos pela liberdade de comunicação e de expressão à propaganda eleitoral negativa. A relevância do tema reside na constatação de que, na atualidade, estão disponíveis diversos meios para divulgação ampla das críticas aos candidatos que, feita corretamente, pode ser salutar, mas, sem limites, é contrária ao objetivo da proteção da livre manifestação. Ao longo do texto, explicam-se brevemente as formas de propaganda política, dentre elas a propaganda eleitoral, pincelando a respeito das vedações infraconstitucionais ao conteúdo das manifestações públicas de opinião relativas a candidatos em época de processo eleitoral. Em seguida, trata-se da abrangência da liberdade de expressão como direito fundamental, bem como da importância de se observar o interesse público como garantia da democracia. Por fim, estuda-se a jurisprudência correlata, para se concluir acerca dos contornos aceitos da propaganda eleitoral negativa.
\end{abstract}

PALAVRAS-CHAVE: Propaganda Eleitoral Negativa; Eleições; Candidatos; Liberdade de Expressão.
ABSTRACT: This article aims to highlight the limits imposed by the freedom of communication and speech to negative electoral propaganda. The relevance of the discussion lies on the understanding that in these days there are numerous means of communication available to wide disseminate criticisms to candidates, what, when done properly, can be salutary to the political process; however, when unlimited, it becomes contrary to the objective of protection of freedom of speech. The different forms of political propaganda are briefly explained throughout the study, among which the electoral propaganda, with a glimpse on the infraconstitutional barriers to the content of public manifestations of opinion about candidates in the electoral year. Then, the extent of the freedom of speech as a fundamental right is dealt with, as well as the relevance of observing the public interest as a safeguard of democracy. Finally, the respective case law is studied, to conclude about the accepted contours of negative electoral propaganda.

KEYWORDS: Negative Electoral Propaganda; Elections, Candidates; Freedom of Speech.

SUMÁRIO: Introdução. 1. Propaganda política. 2. Propaganda eleitoral e limites infraconstitucionais. 3. Liberdade de expressão como princípio e suas limitações. 3.1. Liberdade de expressão e democracia. 3.2. Limites constitucionais à propaganda eleitoral negativa. 4. Propaganda eleitoral negativa na jurisprudência. Consideraç̃os finais. Referências.

\section{INTRODUÇÃO}

A propaganda eleitoral é porventura, tanto como o ato de votar, um importante instrumento da democracia. Sem ela, pouco sentido há no processo eleitoral, haja vista que a soberania popular somente poderá ser exercida em sua plenitude quando permitida a máxima informação, a discussão de ideias, a criação e a divulgação de propostas, a apresentação de candidatos e, porque não, a crítica aos sujeitos do processo eleitoral.

Com isso em mente, o artigo tem por tema as limitações ao conteúdo da liberdade de expressão na propaganda eleitoral negativa, quer dizer, daquela propaganda em que se expõem opiniões contrárias aos candidatos a partir do registro de candidatura.

\footnotetext{
* Mestranda em Direito pela Universidade Federal de Santa Catarina.
} 


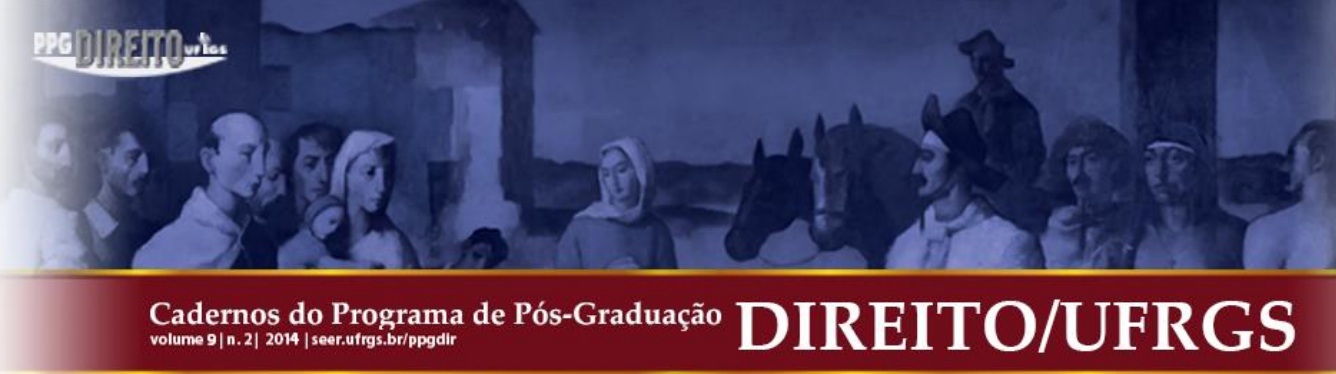

dispõe que: “Ao postulante a candidatura a cargo eletivo é permitida a realização, na quinzena anterior à escolha pelo partido, de propaganda intrapartidária com vista à indicação de seu nome, vedado o uso de rádio, televisão e outdoor.”. Implica dizer que é permitido ao interessado em se candidatar fazer sua promoção entre os filiados a fim de ser escolhido na Convenção Partidária, que se dá entre os dias 12 e 30 de junho do ano eleitoral.

Enfim, escolhido o candidato, inicia-se o período de propaganda eleitoral. Trata-se de "espécie de propaganda que tem a finalidade precípua de divulgar ideias e programas dos candidatos [...] oportunidade que a legislação eleitoral atribuiu ao candidato para exteriorizar o símbolo real do mandato representativo partidário" (RAMAYANA, 2012, p. 442).

Por ser forma de divulgação das propostas de concorrentes aos mandatos eletivos, apresenta nítido interesse promocional para convencer o eleitorado. Diante de tais premissas, poderão constar argumentos que indicam ser o candidato mais apto a exercer o cargo, bem como que demonstrem por que os concorrentes não devem ser escolhidos pelo povo.

Não se confunde, logo, com a publicidade institucional, vez que esta deve ser impessoal, não admitindo promoção do agente público ou político. Da mesma forma, difere da partidária, pois "enquanto esta se destina a divulgar o programa e o ideário do partido político, a eleitoral enfoca os projetos dos candidatos com vistas a atingir um objetivo prático e bem definido: o convencimento dos eleitores e a obtenção de vitória no certame" (GOMES, 2010, p. 313). E, igualmente, não se relaciona com a intrapartidária, pois, além de serem divulgadas em datas diversas, a primeira se destina à indicação do candidato eleitoral dentre os filiados ao partido, enquanto a segunda volta-se para a escolha do mandatário pelo povo.

Feitos os aportes iniciais relativos à matéria a respeito das diversas modalidades de propaganda política/pública (a depender da classificação seguida), a seção que se inicia irá aprofundar especificamente a propaganda eleitoral, a fim de, posteriormente, verificar se existem limitações à liberdade de expressão em caso de divulgação negativa do candidato.

\section{PROPAGANDA ELEITORAL E LIMITES INFRACONSTITUCIONAIS}




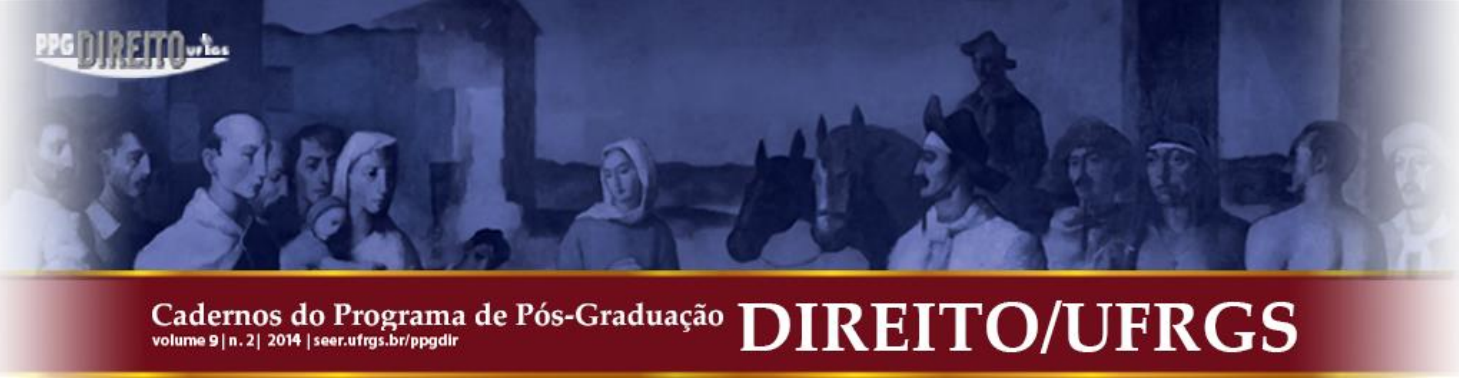

Consoante se observou da elucidação acima, a propaganda eleitoral apresenta caracteres diversos da (intra)partidária e da publicidade institucional, sugestionando a finalidade de obter votos para os cargos eletivos, ao invés de propriamente difundir os programas partidários, escolher os candidatos nas convenções ou divulgar os atos e os serviços da Administração Pública. Nesse tópico, será abordada a propaganda eleitoral, perpassando-se os princípios que regem a matéria, o termo inicial e final para sua divulgação, as classificações, as sanções em caso de propaganda irregular e o direito de resposta.

Como ponto de partida, a doutrina majoritária aponta para alguns princípios que conduzem o tema sob exame, dentre eles o da legalidade, da liberdade, da responsabilidade, da igualdade, da transparência e do controle judicial - vide Cândido (2012), Barros (2012), Ramayana (2012) e Gomes (2010).

Tais princípios, conforme os autores acima, reforçam que o Código Eleitoral (CE) e a Lei das Eleições devem regulamentar a matéria ${ }^{2}$, prevalecendo, entretanto, a liberdade na forma e no conteúdo da propaganda, que não deve ser cerceada nem impedida (a teor do artigo 41 da LE e do artigo 248 do CE), seja ela positiva ou negativa. Em caso de propaganda irregular, são responsáveis os partidos, as coligações e os candidatos quanto aos abusos perpetrados, podendo ser alvos do poder de polícia do Judiciário, que deve primar pela igualdade de condições entre os concorrentes.

Em se tratando da data inicial para sua exposição, existem dois posicionamentos na literatura, vez que a Lei 4.737/1965 e a Lei 9.504/1997 trazem prazos diversos. Para os adeptos do primeiro panorama, a exemplo de Cândido (2012), o artigo 240 do Código Eleitoral permite a propaganda eleitoral a partir da escolha do candidato em Convenções Partidárias. "Escolhido o candidato na convenção, adquire ele - e seu Partido político - o direito de, desde logo, pôr-se à rua com a propaganda, independentemente do deferimento de seu pedido de registro pelo juízo eleitoral competente" (CÂNDIDO, 2012, p. 181).

Posicionamento outro é o adotado pela jurisprudência do Tribunal Superior Eleitoral (BRASIL, 2011) e por Barros (2012), Ramayana (2012) e Zílio (2014), no sentido de admitir a propaganda eleitoral a partir do dia 5 de julho do ano da eleição, forte no artigo 36 da Lei

\footnotetext{
2 Muito embora as resoluções expedidas pelo Tribunal Superior Eleitoral influenciem - com base na competência fixada no artigo 23, inciso IX, do Código Eleitoral - também a propaganda eleitoral, malgrado o artigo 105 da Lei n. 9.504/1997 proibir expressamente a restrição de direitos ou a previsão de sanções distintas daquelas previstas em Lei.
} 


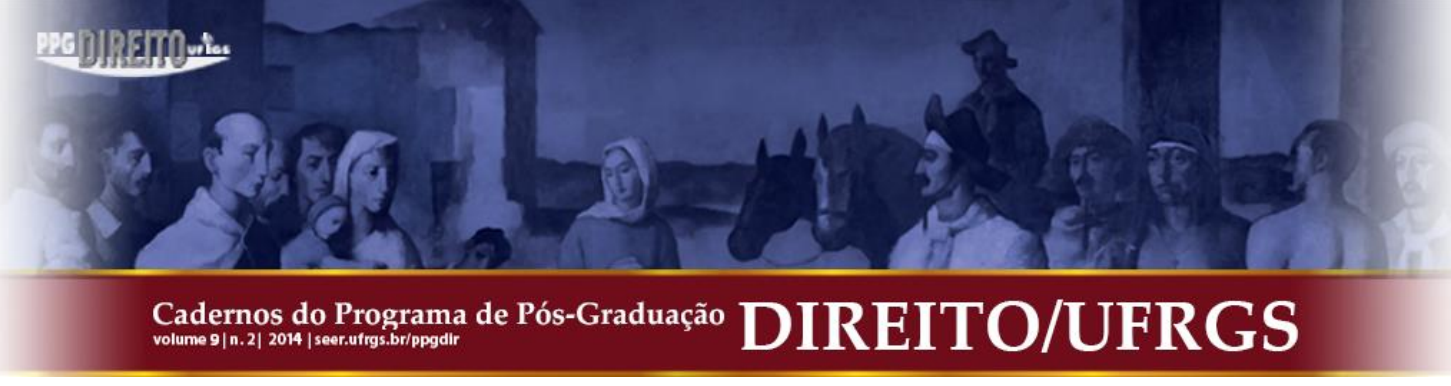

das Eleições, sofrendo revogação tácita o artigo 240 do Código Eleitoral, haja vista ser aquele enunciado mais recente.

Quanto ao fim do prazo para a divulgação da propaganda eleitoral, mesmo existindo diversas leis esparsas que tratam da disciplina, nenhuma delimita o seu termo final, apenas estabelecem algumas restrições nas 48 horas que antecedem o pleito e nas 24 horas seguintes; assim, entende-se que sua divulgação se encerra com o fechar das urnas (CÂNDIDO, 2012).

Passando para sua classificação, costuma-se dividir a propaganda eleitoral pelo conteúdo positivo ou crítico. Naquele, segundo Gomes (2010, p. 313), o candidato é enfatizado, sendo "louvadas suas qualidades, ressaltados seus feitos, sua história, enfim, sua imagem. Já a [propaganda eleitoral] negativa tem por fulcro o menoscabo ou a desqualificação da pessoa, sugerindo que não detém os adornos morais ou a aptidão necessária à investidura em cargo eletivo".

De maior relevo ao estudo é esta última, a propaganda eleitoral negativa, que tem por objetivo alertar os demais eleitores dos motivos pelos quais os concorrentes do candidato não estariam aptos a exercer o mandato pelo qual competem. Nesse sentido, os dizeres de Ramayana (2012, p. 442. Grifos no original):

Fala-se em contrapropaganda como uma forma de atacar as teses do adversário, desmontando os temas, utilizando técnicas de pormenores dúbios da vida privada, o que poderá gerar ofensas à honra e o direito de resposta (art. 58 da Lei $\mathrm{n}^{\circ}$ 9.504/1997), inclusive em alguns casos a análise do tipo penal da calúnia, difamação ou injúria (delitos previstos no Código Eleitoral, arts. 324 a 326).

Quer seja em seu predicado positivo ou negativo, há que se considerar que as leis federais e a Constituição - bem como, às vezes, as resoluções do TSE - impõem limites à liberdade de propaganda e de expressão.

Nesse sentido, distingue-se a propaganda regular, ou legal, da ilícita. De acordo com o princípio da liberdade de propaganda e com os artigos relacionados, se não há proibição normativa, a propaganda eleitoral será considerada lícita, a não ser, é claro, que ultrapasse o alcance garantido à liberdade de comunicação e de expressão.

A propaganda irregular configura-se, portanto, naquela que viola regulações eleitorais, como, por exemplo, o painel que ultrapassa $4 \mathrm{~m}^{2}$ de área. São sanções do ato ilegal elencadas por Gomes (2010): multa (artigos $36, \S 3^{\text {o }} ; 37$, $\S 1^{\text {o e }} 2^{\text {o }} ; 39, \S 8^{\text {o }} ; 43, \S 2^{\text {o }}$; todos da LE), restauração do bem (artigo $37, \S \S 1^{\circ}$ e $2^{\circ}$, da LE), retirada do outdoor (artigo $39, \S 8^{\circ}$, da 


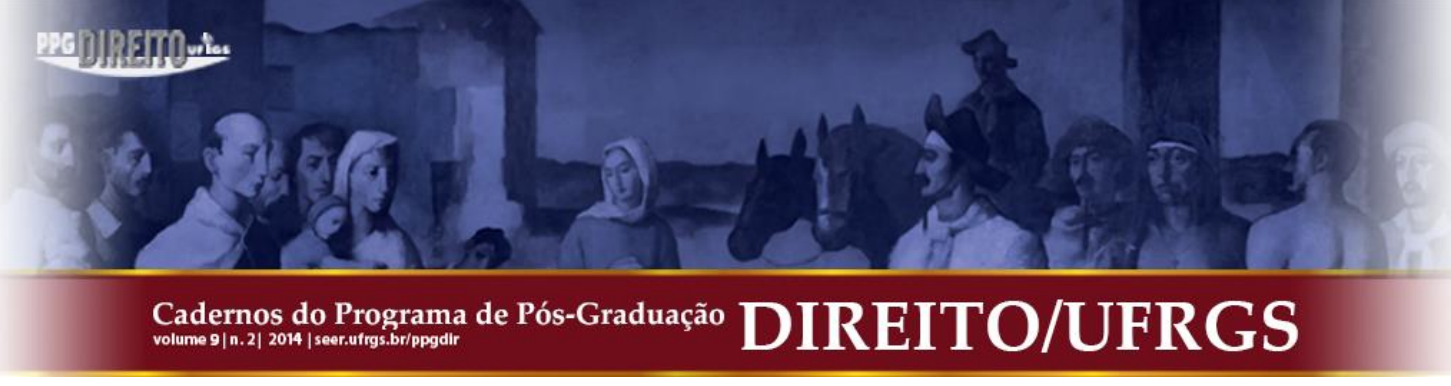

LE), perda do direito à veiculação de propaganda (artigo 53, § $1^{\circ}$, da LE), impedimento de reapresentação de propaganda (artigo 53, $\S 2^{\circ}$, da LE), perda do tempo eleitoral gratuito (artigo 55, Parágrafo único, da LE), suspensão da programação normal da emissora (artigo 56, caput, da LE) e adequação ou retirada da propaganda ( $\operatorname{artigo~} 37, \S 2^{\circ}$, da LE).

Há, igualmente, ao lado das propagandas eleitorais ilícitas, aquelas que a lei tipifica como crime, como a divulgação de fatos inverídicos ou caluniosos (artigo 323 e 324 do Código Eleitoral), a propaganda de candidatos no dia da eleição (artigo 39, § 5 ${ }^{\circ}$, inciso III, da Lei das Eleições), o uso de símbolos associados à Administração Pública (artigo 40 da LE) e a contratação de pessoas para emitir mensagens a fim de ofender a honra ou denegrir a imagem de candidato (artigo 57-H, $\S 1^{\circ}$, da LE).

A propaganda eleitoral negativa poderá, quando irregular ou criminosa, conforme acima elencadas, ensejar representação do atingido no intuito de que lhe seja assegurado o direito de resposta previsto no artigo 58 da Lei 9.504/1997. Não são, todavia, todas as críticas que podem ensejar o exercício do contra-ataque, uma vez que a

[...] crítica veemente, ou a utilização de palavras que apontem os erros da Administração Pública, suas falhas, vicissitudes e ilícitos não ensejam o direito de resposta, porque é de atribuição dos concorrentes nas campanhas eleitorais mostrarem aos eleitores, e a toda a sociedade, as falhas do atual modelo político ou do quadro de servidores públicos, indicando as diretrizes estatutárias que devem ser efetivadas (RAMAYANA, 2012, p. 496)

De acordo com a legislação infraconstitucional, para a configuração do excesso e o consequente direito de resposta, deve a propaganda ser caluniosa, difamatória ou injuriosa, ou seja, constituir crimes, ou ser então sabidamente inverídica. Sucede, contudo, que a última é de difícil ocorrência, pois é tarefa hercúlea delinear quando se trata de conhecida informação inverídica ou quando consiste no exercício do direito de liberdade de comunicação.

A despeito disso, imperioso ressaltar que há outros limites à propaganda negativa: não é apenas a vedação da lei infraconstitucional que constitui empecilho às práticas difamatórias ou injustas dos candidatos - e de terceiros se referindo aos candidatos. A própria Constituição Federal, no que importa à abrangência da liberdade de comunicação e de expressão, também estabelece certos critérios diretos de limitação daquela liberdade, em proteção ao indivíduo e ao interesse público. 


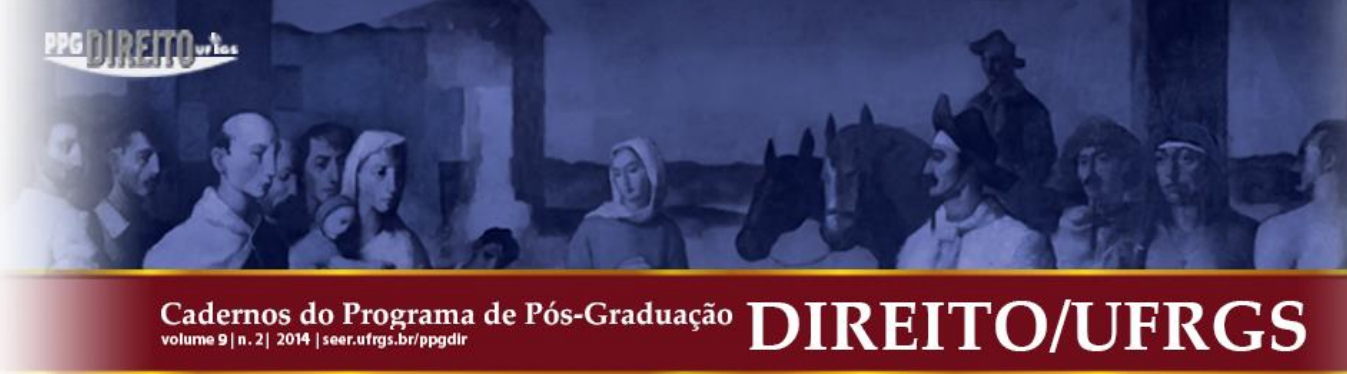

Isso porque, como se verá, a referida liberdade, além de ser um instrumento da democracia, é a medida do que se admite nas campanhas, por resguardar o interesse público e, dessa forma, dar abrigo à soberania popular. Nesse sentido, a proteção constitucional, mais alargada, alcança situações que não necessariamente estão positivadas na legislação eleitoral federal, mas que são de relevância para a lisura da propaganda de campanha, tal como a observância do interesse público e do direito de informação do eleitorado.

\section{LIBERDADE DE EXPRESSÃO COMO PRINCÍPIO E SUAS LIMITAÇÕES}

\subsection{Liberdade de expressão e democracia}

A liberdade de expressão é considerada, para a maioria das sociedades atuais, um direito fundamental, porque essencial à proteção da dignidade da pessoa humana (MACHADO, 2014). No Brasil, assim como ocorreu gradativamente ao longo do último século em diversos outros países ao redor do mundo, chegou a ser consagrada pela Constituição Federal, em seu artigo $5^{\circ}$, inciso IX, como um direito inviolável. E segundo o texto constitucional pátrio, consiste na faculdade de se expressar o que pensa, sem qualquer tipo de empecilho ou censura do Estado, que, por sua vez, deve ratificá-la em todas as suas instâncias.

Sua importância é tamanha porque, como aponta Ferraz (2014), a liberdade como valor é uma das integrantes da personalidade humana, que lhe permite o desenvolvimento da criatividade e de seu próprio ser para a autodeterminação, além de sua participação na construção política, social, econômica e cultural da comunidade. À lei caberia, em seu dizer, apenas equilibrar a liberdade de um indivíduo frente ao outro, para permitir a convivência pacífica, nada mais.

Nesse sentido, sendo a liberdade de comunicação e de expressão um dos mais importantes e indispensáveis pilares de construção da democracia, cabe estudar brevemente a relação entre eles para, mais adiante, adentrar na especificidade dos casos em que se observou a veiculação de propaganda eleitoral negativa, e se esta deve ou não estar inserida no âmbito de proteção daquele direito fundamental. 


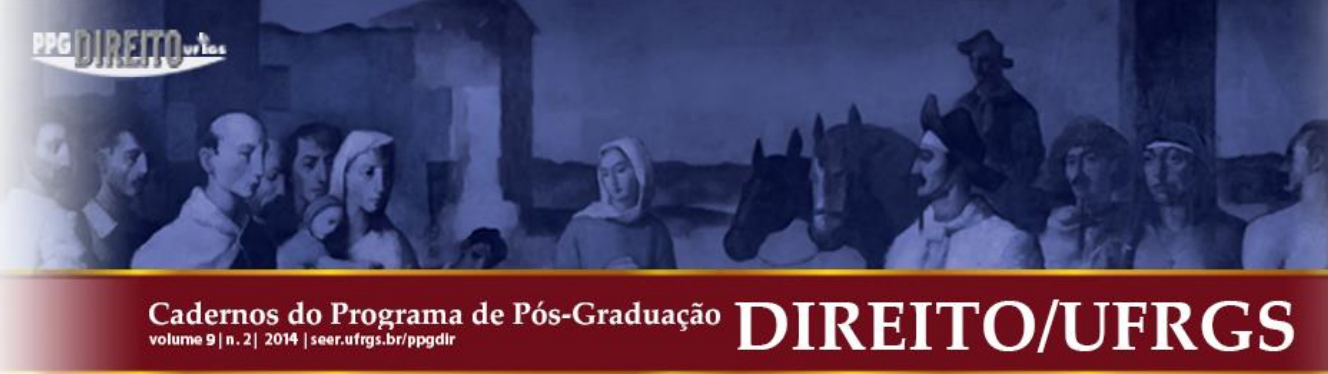

Como se pincelou anteriormente, mesmo que de suma importância para a concretização da democracia, e mais ainda no período eleitoral - especialmente no que toca à propaganda eleitoral -, a liberdade, apesar de plena, não é absoluta.

Por evidente, depende a democracia da possibilidade de comunicar ideias, debatê-las e até contestá-las livremente. Nesse sentido, em sua plenitude, a comunicação e a expressão devem ser protegidas contra qualquer tipo de censura prévia e posterior, assim como contra óbices causados pelos próprios particulares. Não obstante, há que se reconhecer que sobre cada um dos direitos fundamentais incidem limitações, justamente para garantir sua convivência em uma mesma ordem, resguardados todos em seu máximo alcance.

Cabe aqui um breve esclarecimento: parte-se, neste artigo, do pressuposto de que todos os direitos constitucionais fundamentais devem ser tratados com a mesma importância, limitados apenas por seu próprio alcance, cada qual em sua área de atuação, de modo que sempre podem ser efetivados perante os seus iguais, qualquer um em seu máximo grau (em sua plenitude); ou seja, até alcançar suas fronteiras de aplicação. Esse pensamento é compartilhado também por Martins Neto e por Pinheiro (2014). De todo modo, importa estudar o posicionamento de outros juristas, tendo em vista que todos convergem para a mesma conclusão: a liberdade não é, e nem poderia ser, ilimitada.

A respeito do tema, Reale Júnior (2010), ao se propor realizar a análise de julgados das cortes superiores brasileiras que enfrentaram diretamente, pela primeira vez, a questão das limitações da liberdade de expressão frente aos demais princípios constitucionais - os quais o autor denomina valores constitucionais -, coloca o direito à manifestação livre do pensamento no mesmo patamar que as demais pilastras do Estado Democrático.

De acordo com a análise dos votos dos Ministros nas decisões estudadas pelo doutrinador, não há dúvidas que há restrições ao exercício da liberdade de expressão. Aliás, limitações essas que são características da própria liberdade, cujos contornos se encontram com outros valores fundamentais do texto constitucional, na forma de princípios de proteção à intimidade, à honra, à dignidade da pessoa humana. Todos pautados, todavia, pelo interesse público que pode conter a informação divulgada, ao passo que este lhe confere importância de coisa pública (REALE JÚNIOR, 2010). 


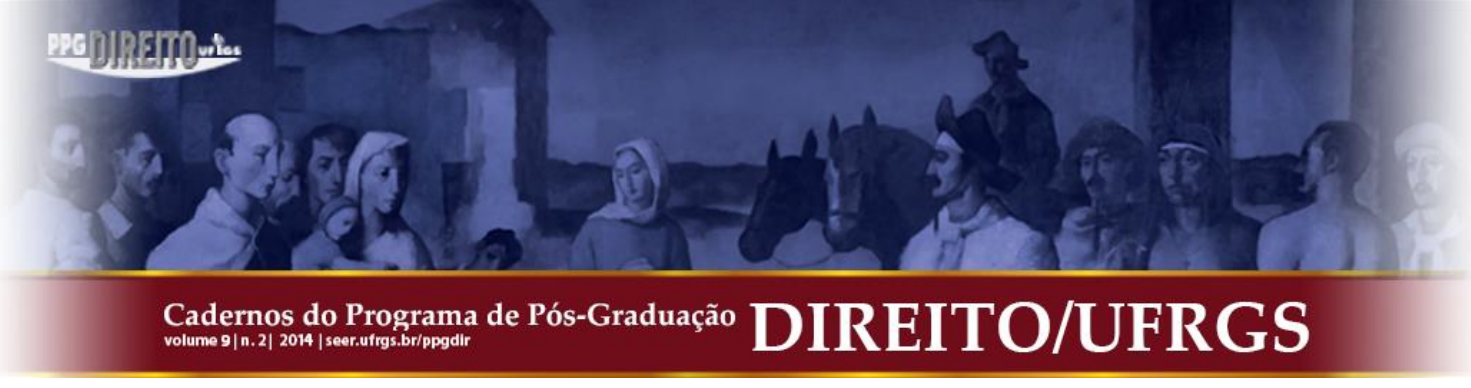

Em um primeiro momento, fica claro que, a despeito de a garantia da liberdade de expressão ser plena (no sentido de que toda a expressão de ideias e de pensamentos é protegida), ela apenas o é quando de acordo com a ordem pública e com os direitos e as garantias de terceiros, nos termos da obra acima. A partir daí, é ilegítima, pois não mais se trata de liberdade, e sim de agressão (calúnia, injúria, difamação, divulgação de segredo de terceiro, de informação inverídica, invasão de privacidade, entre outros).

No mesmo viés, Moraes (2004) compreende que a proteção constitucional à informação não se verifica quando da divulgação de informações de interesse puramente privado, ou de forma vexatória ou humilhante. Por esse motivo, explica que o texto constitucional repele frontalmente qualquer tipo de censura prévia, o que não significa, porém, dizer que a liberdade de expressão seja ilimitada, considerando que pode haver responsabilização posterior quanto àquilo que for expresso ou veiculado. Em suas palavras:

\footnotetext{
A liberdade de imprensa em todos os seus aspectos, inclusive mediante a vedação de censura prévia, deve ser exercida com a necessária responsabilidade que se exige em um Estado Democrático de Direito, de modo que o desvirtuamento da mesma para o cometimento de fatos ilícitos, civil ou penalmente, possibilitará aos prejudicados plena e integral indenização por danos materiais e morais, além do direito de resposta (MORAES, 2010, p. 52).
}

No caso da propaganda eleitoral, desse modo, fica evidente, porventura mais do que outras expressões de pensamentos e de ideias, que ela deve se pautar pela divulgação apenas daquilo que se pode considerar de interesse público, sem caráter vexatório e com o cuidado de não estar na forma de exortação contra outro candidato e outros sujeitos do processo eleitoral.

Aqui, então, retira-se do âmbito de proteção da liberdade de expressão, por exemplo, a calúnia, a injúria, a difamação, a violação da privacidade (composta por tudo aquilo que não seja de interesse público), a divulgação de segredo legítimo, a ameaça, a incitação e até a informação sabidamente inverídica. Todas essas já vedadas pelo nosso ordenamento jurídico infraconstitucional. Do mesmo modo, importante que as informações divulgadas sejam adquiridas licitamente e observado o zelo em sua obtenção, conquanto eventualmente errôneas.

Não poderia ser de outra forma, principalmente em assunto que toca diretamente o exercício da cidadania. Se, por um lado, é importante que se proteja a integridade das informações veiculadas pelos candidatos, assim como a variedade do seu conteúdo, inclusive 


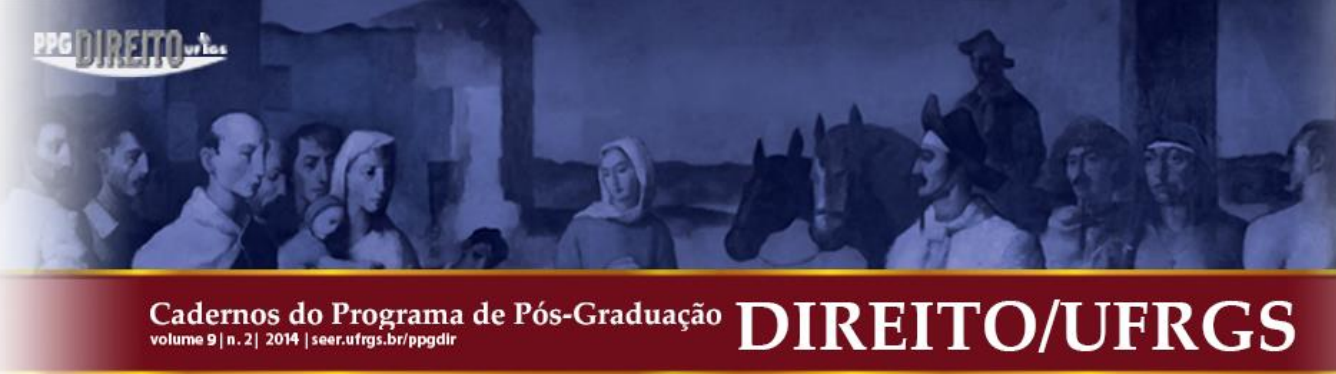

criticando seus oponentes no que for cabível, por outro, é prejudicial ao processo eleitoral que essa crítica seja desonesta ou irresponsável, porque cria entraves ao desenrolar sadio do pleito.

Pois bem, ademais das limitações incontestes da liberdade de expressão, conforme se demonstrou acima, o que a separa da privacidade e lhe garante plena proteção é a identificação de seu conteúdo com o interesse público.

Respeitadas as demais garantias e permitida amplamente a exposição da opinião, até mesmo da crítica, não há equívoco em afirmar que a liberdade de se expressar na propaganda eleitoral só alcança o que seja de legítimo interesse público, daí pouco importando se a sua comunicação se faz por meio escrito, falado, televisivo ou pelo uso da internet. Trata-se da determinação do alcance da liberdade.

Como explica Póvoas (2002), o interesse público, apesar de se tratar de um conceito vago, não é uma expressão arbitrária, dada a sua importância como verdadeiro limitador da liberdade.

Nessa toada, na doutrina (JUSTEN FILHO apud POVOAS, 2002), elencam-se ao menos quatro definições do que seria o interesse público: seria ele a conjugação dos interesses individuais conscientes; os interesses homogêneos, que transcendem a individualidade; a conjugação dos interesses individuais em um determinado ambiente; ou, o mais aceito, a satisfação de interesses de segmentos da população, em momentos determinados, para a realização de seus direitos fundamentais e pela busca da dignidade humana.

Assim, o interesse público se relaciona não apenas com os direitos fundamentais da coletividade (entre eles o direito de receber informações e a liberdade de divulgá-las), mas também com a obrigação que se impõe aos governantes de verificar, em todos os casos, quando se está diante de informações que sejam legitimamente de interesse público, para lhes conferir a proteção necessária.

Se, por um lado, a liberdade de expressão não alcança a intimidade e a privacidade alheias, por limitação constitucional, por outro, se considera privado apenas aquilo que não seja de interesse público, porque o fato deixa de fazer parte da privacidade do indivíduo quando tenha relevância social, podendo gerar efeitos na vida comunitária, ou quando tenha “transcendência pública" (JUSTEN FILHO apud POVOAS, 2002, p. 41).

Nesse ínterim, como já se mencionou, até a crítica, desde que medida e séria, e dessa forma, voltada ao engrandecimento da sociedade e não ao desprestígio ou à exposição ao 


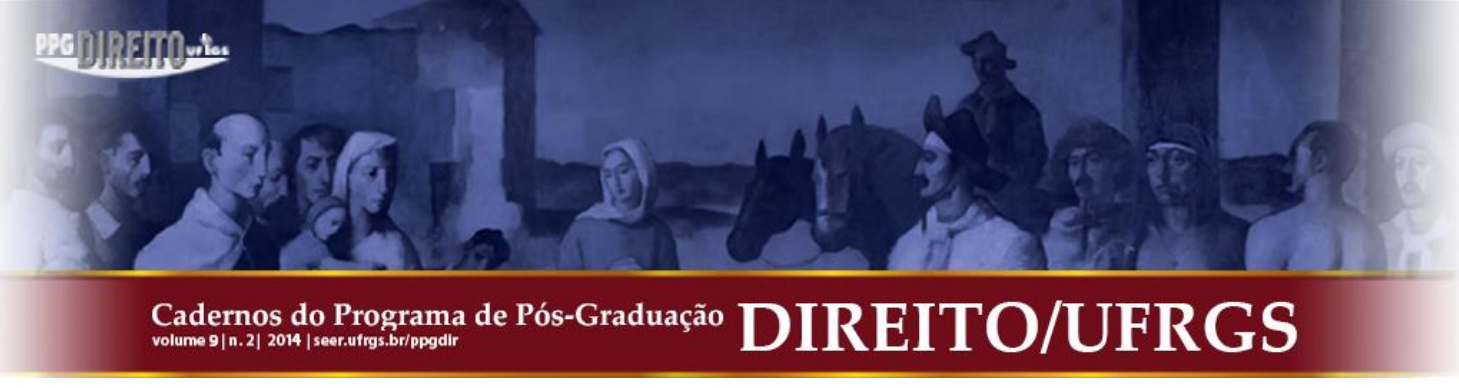

ridículo do criticado, tem sua função de existir, sendo também importante a sua proteção por se enquadrar no direito à liberdade de manifestação do pensamento.

Não obstante, o abuso da liberdade, divulgando informações que, adentrando na esfera íntima, não gozem de interesse público, por certo não há de ser tolerado. Esse tipo de atividade encontra contradição, inclusive, com o fundamento constitucional da dignidade da pessoa humana, com o direito à honra e com a proteção à vida privada, na medida em que converte em entretenimento (mas não em interesse público), assuntos de natureza íntima, e, por vezes, acarreta injustificados e irreparáveis danos ao atacado (MORAES, 2004).

Faz-se uma breve consideração: há que se diferenciar o interesse público (que é aquele legítimo, conforme acima explicado), do interesse do público, como acontece pelo "interesse" pelos acontecimentos das vidas das celebridades, ou pela curiosidade pela vida alheia em geral. Segundo Mendes (2007), não são expressões coincidentes, porquanto aquele é apenas o necessário para informar o público e para proteger sua saúde e segurança, enquanto este estaria baseado, por vezes, em um sentimento de "execração" pública. Ao interesse do público, portanto, não se confere proteção quando adentra a vida privada, ou fere a dignidade, porque, além de não contribuir para a coletividade, tende a prejudicar os envolvidos.

Ainda assim considera-se que, no que toca aos agentes públicos e políticos, a esfera de interesse público é mais alargada e, segundo alguns estudiosos, vide Moraes (2004), a proteção constitucional da intimidade deve ser, quanto a eles, interpretada restritivamente, já que suas atividades profissionais exigem maior exposição à mídia. Não se permite, entretanto, também para esses casos, que se façam ofensas desarrazoadas, desproporcionais ou sem nexo de causalidade com a profissão ou com a atividade da pessoa.

Em resumo: a liberdade de expressão é elemento essencial e indispensável da democracia. Não significa dizer, porém, que ela seja ilimitada, tendo seu alcance no que não possa causar dano injustificado a outrem (hipóteses definidas na lei infraconstitucional), bem como no que pode ser legitimamente considerado como de interesse público. Do mesmo modo, no que diz respeito à propaganda eleitoral negativa, ela deve servir como instrumento para a boa eleição, ao aprofundar o debate a respeito dos candidatos, com vistas ao que possa afetar a coletividade, desde que não cause injustificado mal com intuito de agressão.

\section{PROPAGANDA ELEITORAL NEGATIVA NA JURISPRUDÊNCIA}




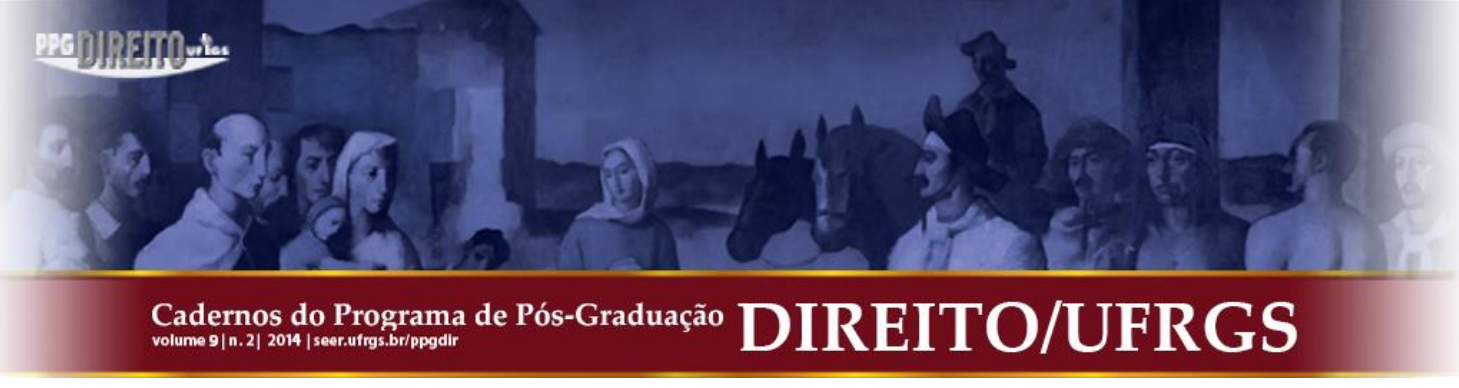

É inevitável que surjam calorosos debates que circundem a seara do Direito Eleitoral, especialmente em ano de escrutínio. Inúmeras críticas políticas vêm à tona, muitas delas ressuscitadas de pleitos passados, as quais concernem, principalmente, aos financiamentos de campanha, à publicidade institucional, à propaganda eleitoral, à divisão do tempo de propaganda gratuita, à Lei da Ficha Limpa, dentre outras questões caras à política.

Na sociedade em rede descrita por Castells (2005), não há como olvidar, paralelamente, que as novidades do mundo eletrônico alteram o cenário das eleições, seja pelo uso constante das redes sociais, pela diversidade de informações divulgadas e pela multiplicidade de formadores de opinião, além de outras possibilidades intrínsecas e inenarráveis do uso da rede.

É salutar que os cidadãos, assim como os próprios candidatos, expressem preferências e discordâncias com os concorrentes aos mandatos, e assim tem ocorrido muito calorosamente pelas vias digitais. A par do cenário eletrônico, o artigo procura analisar prática corriqueira entre os usuários da internet, consistente no uso das redes sociais e dos sítios eletrônicos para a crítica ou a defesa dos elegíveis. Delimitando-se a temática, a explanação visa a esclarecer a respeito das consequências da divulgação, em sites, de juízos de valor depreciativos, denominados propaganda eleitoral negativa.

Relembrando os questionamentos feitos até então nos tópicos precedentes - a respeito da liberdade de expressão e dos seus limites constitucionais e infraconstitucionais (a exemplo da Lei das Eleições e do Código Eleitoral) -, chega-se ao seguinte: malgrado se resguarde a liberdade de comunicação e de expressão, existem barreiras no ordenamento, as quais, é claro, impedem a utilização desmedida e irresponsável da garantia. Veja-se, de maneira elucidativa, como já destacado, a vedação ao anonimato, a punição de informações caluniosas, difamatórias ou injuriosas que são confrontados pelo direito à informação e pelo interesse público.

A fim de melhor elucidar tais questionamentos com casos concretos, a pesquisa se volta para o estudo de duas decisões proferidas pelo Tribunal Regional Eleitoral de Santa Catarina. A seleção de ambas ocorreu devido ao fato de relatarem casos de propaganda eleitoral negativa publicizada por meio das redes sociais, bem como pelo teor das postagens virtuais e das decisões abalizadas pelo tribunal catarinense. Para o presente estudo, importa ressaltar, não era necessário nem interessante utilizar decisões provenientes de Recurso 


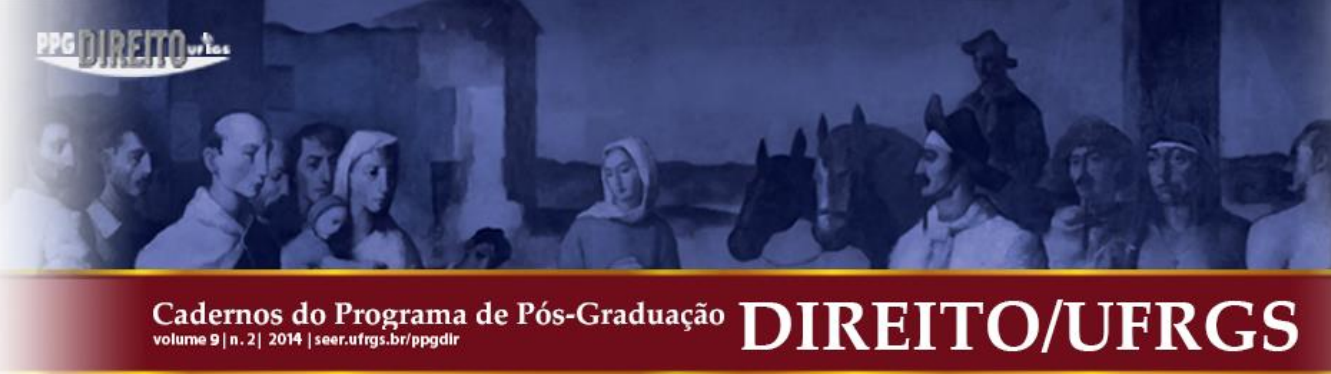

antecipada, tampouco entendeu configurar manifestação apócrifa, vez que o músico autointitulado Giove aparecia fisicamente durante as gravações.

Pois bem, partindo para a análise crítica de ambas as decisões, com base nos limites da liberdade de expressão acima expendidos, entende-se que, na primeira, ainda que se observe ser o vídeo do Recurso Eleitoral n. 249-41 manifestação sem identificação autoral, expressamente vedada pela Constituição Federal e pelo artigo 57-D da Lei 9.504/1997 (que prevê a aplicação de multa e a possibilidade de exclusão da mídia), motivo pelo qual a decisão colegiada soa plenamente defensável, entende-se que o acórdão poderia ter-se imiscuído em outras questões levantadas ao longo do presente trabalho.

Seria também juridicamente possível, destarte, esclarecer que o vídeo se baseia em fatos - como é a publicação de notícia em revista jornalística - e que existe, malgrado o anonimato, sobrepujante interesse da população municipal em conhecer as denúncias de crimes imputados ao concorrente.

Deveras, não se verifica a clara ocorrência de calúnia e de expressões difamatórias capazes de fazer incidir a sanção por propaganda irregular, motivo pelo qual se permitiria a manutenção do vídeo no sítio eletrônico. É de se relembrar, da mesma forma, que o Google, empresa proprietária do site, possui o número de $I P^{3}$ de quem divulgou o arquivo, que pode ser disponibilizado por decisão judicial, afastando-se o argumento jurídico de ausência de identificação. Finalmente, as declarações no clipe se baseiam em recorte da revista Época, fato que demonstra a responsabilidade, em tese, de sua elaboração.

No mais, não se constata intenção de exortação em ofensa ao particular (candidato), mas de alerta aos demais eleitores a respeito de escândalos e casos de corrupção em que esteve supostamente envolvido, mesmo que em fase de julgamento. Pode-se considerar de legítimo interesse da população conhecer a respeito de processos judiciais e até mesmo a respeito de acusações e investigações de que aquele seja parte.

Nesse sentido, deveria ser reformado o posicionamento judicial emitido, para contemplar a liberdade (senão o dever) de manter informados os eleitores, mormente em época eleitoral.

\footnotetext{
${ }^{3}$ IP significa internet protocol e corresponde à identificação única de um dispositivo eletrônico quando se conecta numa rede local ou pública. Para mais informações acesse <www.techtudo.com.br〉.
} 


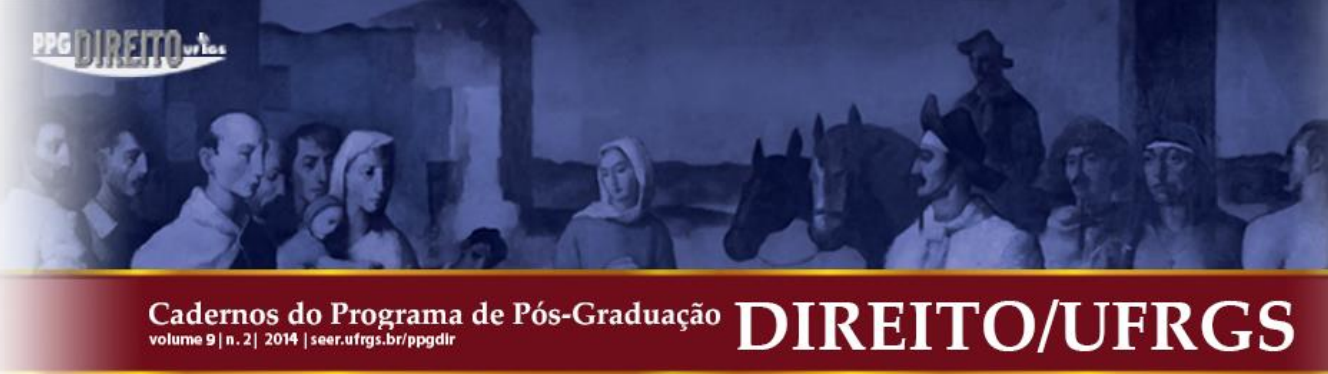

Voltando-se para a segunda decisão, por contrário, pouco se identifica, na canção disponibilizada, conteúdo informativo ou que objetivasse a preservação do interesse público. Em verdade, a mídia digital apresenta caráter exortativo contra a candidata, relacionando sua imagem a figuras como "bicho feio", "agressivo", "animal”, "criatura", dentre outras, o que a agride pessoalmente, ao invés de engrandecer a discussão em época de pleito.

Não se visualiza, portanto, intenção cidadã ao encontro da democracia, senão em revés: é com intento perverso e pernicioso à eleição, por nem ao menos conferir-lhe a seriedade que lhe é devida. Desse modo, novamente, conclui-se contrariamente à decisão do juízo, porque, conquanto este não reconheceu o fumus boni juris necessário para conceder a medida cautelar, a análise em conjunto com os objetivos da liberdade de expressão e de comunicação e com as limitações infraconstitucionais (que também dela advêm) parece demonstrar que a "expressão" possui conteúdo malicioso, com o qual a candidata não deve ser obrigada a conviver.

Não se trata da supressão da liberdade daquele que disponibilizou o vídeo (haja vista que a liberdade não tem alcance ilimitado), mas da proteção da imagem e da dignidade do recipiente, e ao mesmo tempo de impedir a ilícita conturbação do processo eleitoral.

\section{CONSIDERAÇÕES FINAIS}

Durante o processo eleitoral, procura-se dar voz aos cidadãos e aos candidatos para que expressem suas opiniões e suas preferências a respeito de quem deve representar politicamente o povo. Atua como balizadora desse processo a legislação eleitoral, importante instrumento de efetivação da soberania popular - muito embora se reconheça a necessidade de reformas políticas de base em diversas matérias -, que tem como linha mestra garantir o pleno exercício da democracia. Para tanto, prevê-se uma gama de oportunidades de manifestação, por intermédio da propaganda eleitoral, permitido o uso das mais diversas formas de difusão (rádio, televisão, internet, placas, jornais).

Com efeito, observa-se que, ao longo da campanha até o escrutínio, as novas tecnologias se tornaram ferramentas que proporcionam maior participação de candidatos (muitos com desvantagens de tempo no horário político gratuito) e de eleitores no destino de seu país, de seu estado e de seu município, especialmente pela internet, em que estão disponíveis alternativas de debate e de informação. 


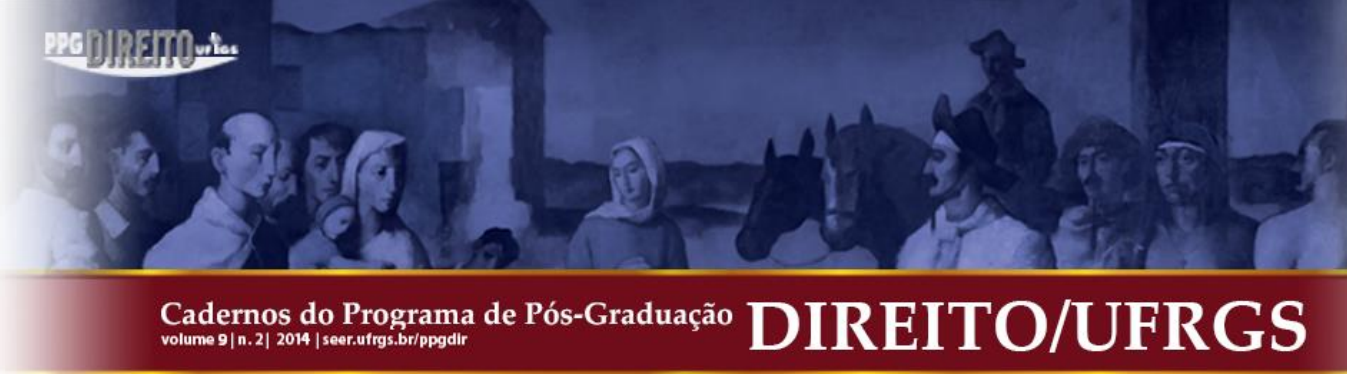

É justamente a garantia da liberdade de expressão e de comunicação que preconiza sejam os conteúdos compartilhados, as ideias discutidas e as propostas criticadas, tudo em favor da tomada de decisão livre e consciente, características sem as quais se perde o objetivo da ampla participação no processo eleitoral. Daí a importância da garantia da livre expressão e da livre crítica, em especial quanto aos assuntos relacionados às eleições, porque diretamente ligados aos propósitos daquelas liberdades. Como se concluiu ao longo do texto, a liberdade de expressão (e, nesse contexto, também a liberdade de imprensa) não é apenas garantia fundamental dos indivíduos, mas de toda a coletividade, vez que influencia diretamente a vida pública.

Para que a participação política seja construtiva, entretanto, indispensável se faz que a divulgação de informações seja, para além de livre, também responsável. Não se protege, porque, aliás, surpassa os limites da própria liberdade, a manifestação com intuito malicioso, que atente contra a privacidade, contra a imagem ou contra a honra do indivíduo, bem como aquela que se faz sem a identificação do emissor (apócrifa). E esses impedimentos, como deve ocorrer, são encontrados tanto no texto infraconstitucional, como na Constituição Federal, esta de onde se retira, ainda, outra contenção: o interesse público.

O que se tentou demonstrar é que o verdadeiro limitador da liberdade de criticar e de apresentar "verdades inconvenientes" é o alcance do interesse público (que de maneira alguma se confunde com boatos e difamações) no que respeita ao conteúdo veiculado. A par disso, ainda que as legislações federal e constitucional prevejam uma série de limites à livre crítica, especialmente quando se tem em voga a propaganda eleitoral negativa, a análise do caso concreto enseja uma percepção constitucional mais alargada, privilegiando-se o interesse social, mas não das colunas sociais, relativo às restrições elencadas, mormente primando-se a máxima informação, a discussão de ideias e de propostas, a apresentação de candidatos e, sem olvidar, a crítica eleitoral.

\section{REFERÊNCIAS}




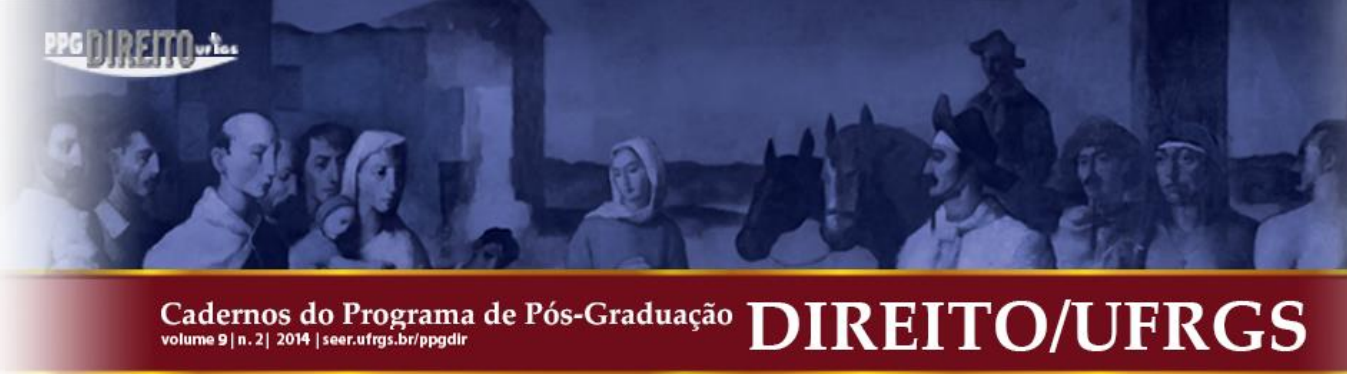

FARIAS, Edilson Pereira de. Liberdade de expressão e comunicação: teoria e proteção constitucional. 2001. 287 p. Tese de Doutorado (Doutorado em Direito). Centro de Ciências Jurídicas, Universidade Federal de Santa Catarina, Florianópolis, 2001.

GOMES, José Jairo. Direito Eleitoral. 5.ed. Belo Horizonte: Del Rey, 2010.

FERRAZ JÚNIOR, Tércio Sampaio. Garantias constitucionais à liberdade de expressão comercial. 2000. Disponível em: <http://www.pge.sp.gov.br/centrodeestudos/revistaspge/revista3/rev1.htm > Acesso em: 20 ago. 2014.

MACHADO, Natália Paes Leme. A "Plena" Liberdade de Expressão e os Direitos Humanos: Análise da Jurisprudência da Corte Interamericana de Direitos Humanos e o Julgamento da ADPF 130. Revista de Direito Internacional (Brazilian Journal of International Law), v. 10, n. 2, 2014.

MARTINS NETO, João dos Passos. Fundamentos da liberdade de expressão. Florianópolis: Insular, 2008.

MARTINS NETO, João dos Passos; PINHEIRO, Denise. Liberdade de Informar e Direito à memória - uma crítica à ideia do direito ao esquecimento. Revista Novos Estudos Jurídicos, v. 19, n. 3, p. 808-830, set./dez. 2014. Disponível em: <siaiweb06.univali.br/seer/index.php/nej/article/download/6670/3805>. Acesso em 03 dez. 2014.

MENDES, Gilmar Ferreira [et. al.]. Curso de direito constitucional. São Paulo: Saraiva, 2007.

MORAES, Alexandre de. Constituição do Brasil Interpretada e Legislação Constitucional. Editora Jurídico. 4 ed. São Paulo: Atlas, 2004.

. Direito Constitucional. 25 ed. São Paulo: Atlas, 2010.

PINHO, José Antonio Gomes de; SACRAMENTO, Ana Rita Silva. Accountability: já podemos traduzi-la para o português? Revista de Administração Pública, Rio de Janeiro, v. 43, p. 1343-1368, nov./dez. 2009. Disponível em: <http://www.scielo.br/pdf/rap/v43n6/06.pdf>. Acesso em 31 jul. 2014. 


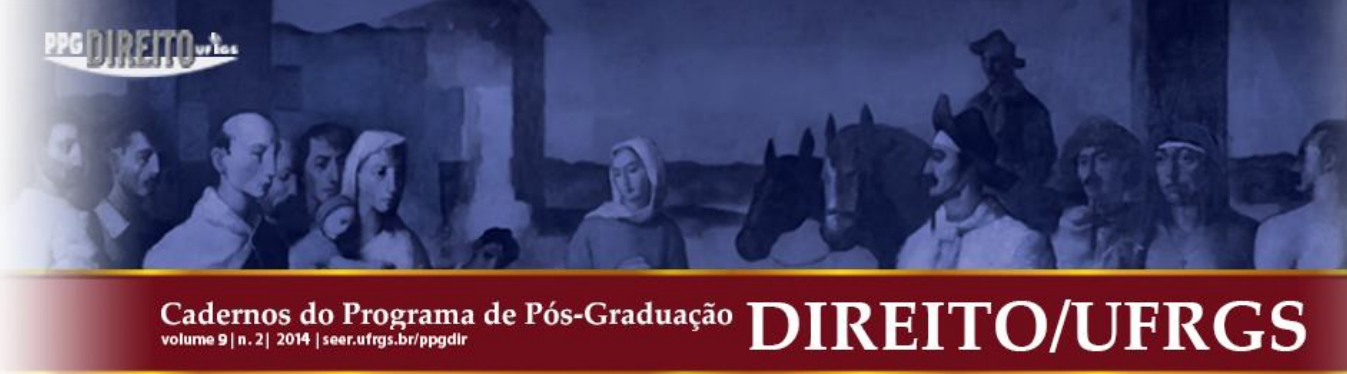

PÓVOAS, Monike Silva. Conflitos entre a liberdade de imprensa e o direito à privacidade. 2002. 80 p. Monografia de Conclusão de Curso (Graduação em Direito). Centro de Ciências Jurídicas, Universidade Federal de Santa Catarina, Florianópolis, 2002. p. 15.

RAMAYANA, Marcos. Direito Eleitoral. 13. ed. Rio de Janeiro: Impetus, 2012.

ROLLO, Arthur Luis Mendonça. Formas de propaganda eleitoral permitidas e proibidas. Propaganda Institucional - vedação nos três meses anteriores ao pleito. In: ROLLO, Alberto (org.). Propaganda Eleitoral: Teoria e Prática. São Paulo: Editora Revista dos Tribunais, 2002.

SANTA CATARINA. Tribunal Regional Eleitoral de Santa Catarina. Medida Cautelar $n$. 1088807 SC. Relator: Francisco José Rodrigues de Oliveira Neto, Data de Julgamento: 26/08/2010, Data de Publicação: Diário de Justiça Eletrônico, Tomo 161, Data 02/09/2010, p. 6-7.

. Tribunal Regional Eleitoral de Santa Catarina. Recurso Eleitoral n. 24941.2012.6.24.0005. Relator Juiz Ivorí Luis da Silva Scheffer. Recorrentes e Recorridos: Google Brasil Internet Ltda. e Coligação "Tenho Brusque no Coração" (PP/PDT/PT/PMDB/PR/PPS/PHS/PTC/PCdoB). Data de Julgamento: 05/06/2013. Data de Publicação: Diário de Justiça Eletrônico de 11/06/2013, n. 104, p. 3-4. Acórdão n. 28239.

STEINBERG, Charles. Meios de Comunicação de Massa. São Paulo: Cultrix, 1972.

ZÍLIO, Rodrigo. Direito Eleitoral: noções preliminares, elegibilidade e inelegibilidade, processo eleitoral (da convenção à diplomação), ações eleitorais. 4. ed. Porto Alegre: Verbo Jurídico, 2014. 